ARTICLE

\title{
Teaching in multilingual classrooms: strategies from a case study in Portugal
}

\author{
Nikolett Szelei' (D) \\ Ana Sofia Pinho" (D) \\ Luís Alexandre da Fonseca Tinoca" (D)
}

\begin{abstract}
This study examined teaching practices developed by teachers to respond to linguistic diversity in a Portuguese case study. We analysed the position that students' languages received in the classroom, and what these practices revealed about teachers' awareness of multilingual pedagogies, a step to social justice. Three main strategies emerged: promoting Portuguese without involving students' languages, using a common language (English) as lingua franca, using students' languages. These strategies appeared in a dynamic way as teachers tried to satisfy the aims of developing the language of schooling, communicating with students and valuing students' linguistic identities. Prioritising Portuguese language dominated, and the strategies were enacted through monolingual views, indicating little awareness of multilingual pedagogies. Thus, the need to support teachers in transforming practices in multilingual classrooms is emphasised.
\end{abstract}

KEYWORDS

multilingualism; linguistic diversity; pedagogy; teachers, classroom practices.

'Centre for the Social Study of Migration and Refugees, Department of Social Work and Social Pedagogy, Ghent University, Ghent, Belgium.

"Instituto de Educação, Universidade de Lisboa, Lisboa, Portugal. 


\title{
ENSINAR EM SALAS DE AULA MULTILÍNGUES: ESTRATÉGIAS DE UM ESTUDO DE CASO EM PORTUGAL
}

\author{
RESUMO
}

Este estudo explorou práticas de ensino desenvolvidas por professores como resposta à diversidade linguística num estudo do caso em Portugal. Analisamos a posição das línguas dos alunos em sala de aula e o que essas práticas revelam sobre a consciência dos professores sobre pedagogias multilíngues como promotoras de justiça social. Três estratégias principais emergiram: promover a língua portuguesa sem envolver as línguas dos alunos; usar uma língua comum (o inglês) como língua franca, e usar as línguas dos alunos. Essas estratégias surgiram de forma dinâmica no modo como os professores procuram o desenvolvimento da língua da escolarização, comunicam-se com os alunos, e valorizam as identidades linguísticas dos alunos. A priorização da língua portuguesa é dominante e as estratégias reforçam perspectivas de monolinguismo, indicando pouca consciência das pedagogias multilíngues. Assim, reforça-se a necessidade de apoiar os professores de forma a transformar as práticas em salas de aula multilíngues.

\section{PALAVRAS-CHAVE}

multilinguismo; diversidade linguística; pedagogia; professores; práticas de sala de aula.

\section{LA ENSEÑANZA EN CLASES MULTINGÜES: ESTRATEGIAS DE UN ESTUDIO DE CASO EN PORTUGAL}

\section{RESUMEN}

Este estudio examinó las prácticas docentes desarrolladas por profesores como respuesta a la diversidad lingüística existente en Portugal a través de un estudio de caso. Analizamos la posición de los idiomas de los estudiantes en aula y lo que estas estrategias revelaron sobre la concienciación de pedagogías multilingües, promotores de la justica social, en los profesores. Surgieron tres estrategias principales: promocionar el portugués sin tener en cuenta las lenguas de los estudiantes, usar una lengua común (el inglés) como lengua franca, usar las lenguas de los estudiantes. Esas estrategias aparecieron de una manera dinámica mientras los docentes intentaban desarrollar la lengua de escolarización, comunicar con los estudiantes y valorar sus identidades lingüísticas. Primar la lengua portuguesa fue la estrategia dominante y las estrategias se implementaron a través de puntos de vista monolingües, indicando poca conciencia de las pedagogías multilingües. Por esa razón, enfatizamos la necesidad de apoyar a los profesores para un cambio de las prácticas en clases multingües.

PALABRAS CLAVE

multilingüismo; diversidad lingüística; pedagogía; docentes; prácticas en el aula. 


\section{INTRODUCTION}

Linguistic diversity is a prominent feature of many classrooms today. While students carry complex linguistic repertoires and identities, it remains an issue how these complexities are in fact valued and mobilized in learning and in school life. Multilingual students still often experience predominantly monolingual school mechanisms, reinforcing the "monolingual habitus" (Gogolin, 2002). As an alternative, multilingual education offers possibilities to transform for the "multilingual habitus" (Benson, 2014) that affirms students' linguistic repertoires in the teaching-learning process, including those minoritized (Hélot and Ó Laoire, 2011). Multilingual education that redefines power relations between languages and provides space for those historically and contemporarily marginalized in society through pedagogical acts, can serve as a platform to strive for the ideal of social justice (Skutnabb-Kangas et al., 2009). However, monolingual ideologies that often shape teachers' perspectives and practice (Tarnanen and Palviainen, 2018; Rodríguez-Izquierdo, Falcón and Permisán, 2020) and everyday pedagogical dilemmas in the multilingual classroom (Ticheloven et al., 2019) still make such a transformation difficult. A lack of social justice orientation in teacher education for diversity (Vargas and Sanchueza, 2018) in which language has a central position (Ball and Tyson, 2011), might also contribute to the challenges of multilingual school practice.

These issues are contemporarily relevant across the globe, and in Portugal too. Especially urban regions in Portugal have been linguistically complex, which has more recently been nuanced by migration from countries where Portuguese is not an official language (Oliveira and Gomes, 2018). Despite these dynamic linguistic changes, there is little up-do-date research on what strategies mainstream teachers develop in the classroom, how students' languages are positioned, and whether these practices indicate awareness of multilingual pedagogies as a step toward social justice. It is a specifically interesting issue to study in Portugal, since the country does not have a long history in developing systemic educational responses to multilingualism in terms of supporting migrant and minoritized languages. In the likely absence of structural support, it is important to investigate how teachers get along in their everyday school practice, and how it possibly impacts multilingual students.

\section{THEORETICAL PERSPECTIVES AND LITERATURE REVIEW}

Linguistic diversity here is approached through the lens of social justice (Piller, 2016; Skutnabb-Kangas et al., 2009). As Piller (2016, p. 14) explains,

In sum, diversity - including linguistic diversity - is a characteristic of all human societies. However, the principle of universal social diversity is complemented by the principle of stratification: the social meaning of linguistic diversity is rarely "different but equal"; much more frequently linguistic diversity forms the basis for inequality.

Inequalities may manifest in, for example, the ways school policies and practices disregard students' languages and position identities as underachievers 
in education, possibly resulting in further marginalization and the maintenance of privileged statuses of dominant languages and their members in society (Skutnabb-Kangas et al., 2009). For example, languages of newly arriving students usually hardly receive structural recognition, and students are less thought of as $\mathrm{bi} /$ multilingual learners, but rather as having a deficit, and as a "problem" (e.g., Agirdag, 2010; De Angelis, 2011; Rodríguez-Izquierdo, Falcón and Permisán, 2020). Furthermore, Shohamy (2006, p. 2) asserts that, through producing language norms, individuals are often assigned to separate groups such as "nation" or "other groups", strictly prescribing ways of being and belonging. Schools are such places where languages and linguistic identities are positioned and embedded in social and institutional practice (Miller, 2004, p. 295), often reflecting hierarchies between languages and members of language groups in society. Schools are also framed by language policies, here understood as "a complex sociocultural process" constructed in "human interaction, negotiation, and production mediated by relations of power" (McCarty, $2004 ; 2011)$. In other words, establishing language policies is a multi-layered process through which norms are created about languages and language use, driven by language ideologies, often resulting in producing social hierarchies (McCarty, 2011). However, language policies are created through a number of explicit and implicit mechanisms, and the relationship between policy and practice is dynamic; it is through these mechanisms that negotiation can happen and "battles for power and control, visibility and voice... take place" (Shohamy, 2006, p. 55). In this article, teaching strategies are regarded as such mechanisms through which monolingual school policies and the multilingual reality of schools can be negotiated. Specifically, we see multilingual pedagogies as potential pedagogical bridges for social justice. However, these negotiation processes depend on 'teachers' beliefs, experiences, existing pedagogical practices and the context" (Kirsch, 2018, p. 445).

Multilingual pedagogies are assemblages of several strategies that build on the ideas of actively involving students' languages in the teaching-learning process as beneficial for students' social, language, and academic development (Cummins, 2005), and carry the possibility of redefining majority-minority language relations in schooling (Skutnabb-Kangas et al. 2009). Multilingual pedagogies emphasize working with students' whole linguistic repertoires, fostering metalinguistic awareness, and building on linguistic diversity of the classroom (Cenoz and Gorter, 2013). Hélot and Ó Laoire (2011) identify the main principles of multilingual pedagogies in acknowledging diversity and changing identities in migration contexts, transcending traditional barriers when implementing a multilingual curriculum, and building on students' metalinguistic awareness in the classroom, this way redefining power relations related to minority languages. Multilingual pedagogies can apply a variety of approaches such as language awareness, intercomprehension, content and language integrated learning, and translanguaging; and it is best to integrate them into a holistic multilingual curriculum and a teaching-learning environment (Meier, 2014). It is also important to keep in mind that each multilingual setting is unique, and it is hard to define a set educational model that suits all. García and Sylvan (2011) remind us of the principle of "singularities in plurality" for multilingual classrooms by which they mean "we must learn to focus on teaching individuals 
within multilingual classrooms in which the plurality is created by paying attention to the singularity of the individual student" (García and Sylvan, 2011, p. 386). Their guiding principles for multilingual schools are fostering collaboration among students and faculty, creating learner-centered classrooms, integrating language and content, building multilingualism from students up, applying experiential learning and localizing autonomy and responsibility. In sum, multilingual pedagogies, although their being manifested in several different instructional strategies, share the underlying assumptions of valuing, fostering, and actively building on students' whole linguistic repertoires, skills, and identities. What concerns this article is that multilingual pedagogies can be seen as negotiating activities through which migrant and minoritized languages, that are usually misrecognized or silenced in school, could gain recognition at a classroom level, even in restrictive policy environments (Hélot and Ó Laoire, 2011; Mary and Young, 2018).

Teachers play an essential role by their opinions on linguistic diversity, and their skills and opportunities to take pedagogical actions in the classroom (Hélot and Ó Laoire, 2011; de Mejia and Hélot, 2015). Therefore, teachers are advised to develop critical language awareness, the knowledge about how to use, analyze, and teach languages while aiming at transforming the taken-for-granted norms of languages in school and society (García, 2017). However, there are a number of reasons that might affect the ways mainstream teachers can negotiate linguistic diversity, if at all. For example, teachers' beliefs, attitudes, and ideologies toward linguistic diversity and migrant and minority language students can shape pedagogical solutions. Recent studies show that although teachers view multilingualism as an advantage in general, they still tend to hold monolingual assumptions about languages and learning (De Angelis, 2011; Pulinx, Van Avermaet and Agirdag, 2017); lower expectations and deficit views about migrant students (Agirdag, 2010; Lyons, 2010; De Angelis, 2011; Pulinx, Van Avermaet and Agirdag, 2017), usually driven by monolingual language ideologies (Asker and Martin-Jones, 2013; Gu and $\mathrm{Qu}, 2015)$. On the other hand, teachers' positive views on and accepting attitudes toward linguistic diversity could lead to increased levels of students' feelings of belonging to school (Van Der Wildt, Van Avermaet and Van Houtte, 2017). However, welcoming dispositions do not necessarily lead to teachers actually building on students' languages or students' multilingual profiles in developing teaching strategies (Vaish,2012; Faneca, Araújo e Sá and Melo-Pfeifer, 2016; Haukas, 2016; Tarnanen and Palviainen, 2018). This might be due to the fact that both initial and in-service teacher education often seem inadequate to meet the multilingual school reality (Butcher, Sinka and Troman, 2007; Cajkler and Hall, 2009; Anderson et al., 2010; de Mejia and Hélot, 2015), and teachers tend to struggle to transform their views and practices (Pinho and Moreira, 2012). Consequently, claims for teacher education on the field of multilingualism advise teachers to be knowledgeable on multilingual learners' language development as well as their linguistic repertoires by collaborating with students and families; bridge language and learning; and develop teaching strategies that serve social justice and equity in the multilingual classroom (Anderson et al., 2010). Another explanatory dimension of teachers' constrains can be strict monolingual policy settings in which they are embedded and that 
might influence teachers' thinking and pedagogical actions (Faneca, Araújo e Sá and Melo-Pfeifer, 2016). However, some studies reveal that, even if on a micro-level and with limitations, teachers can negotiate language policies by mobilizing their own multilingual repertoires, dialoguing about languages with students and families, and legitimizing or explicitly encouraging students to use the languages of students' choice in the classroom (Hélot and Young, 2005; Hélot, 2010; Jordens, Van Den Branden and Van Gorp, 2018; Bonacina-Pugh,2017; Kirsch,2018; Mary and Young, 2018). This shows that teachers' strategies in the classroom, even if manifested in small pedagogical actions, can serve as negotiating mechanisms in aiming for multilingual education and social justice.

\section{LINGUISTIC DIVERSITY AND THE PORTUGUESE EDUCATIONAL SYSTEM}

As Tomás et al. (2011) explain, the language of schooling in Portugal is predominantly Portuguese, and its other officially recognized languages are $\mathrm{Mi}$ randese, a regional language, and sign language. However, the linguistic landscape of the country is more diversified than the ones recognized in the language of schooling, particularly in the greater Lisbon area. Several individual small-scale studies report on different languages and their distributions in school contexts. The study of Mateus (2011) reported altogether 80 languages spoken in Portugal, and 58 in metropolitan Lisbon (Pereira, 2006). Two studies (Mateus, 2011; Silva and Gonçalves, 2011) pointed to the largest minority languages in greater Lisbon as Cape Verdean, Creole of Guiné-Bissau, and of São Tomé, Kimbundu, and Ukrainian. Linguistic diversity has shown a more complex character since the 1990s, when students arrived from countries where Portuguese is not an official language; and, consequently, policy initiatives targeted migrant pupils in the form of providing "Portuguese as non-mothertongue language (PNML)" tuition (Tomás et al., 2011). Currently, the PNML curriculum demands offering language support for all PNML students. In the primary years, there is not necessarily a separate PNML subject because basic literacy skills are considered to be acquired at this stage. From $5^{\text {th }}$ grade onward, PNML students are provided PNML classes and they do not visit regular Portuguese lessons as a subject. However, as soon as they reach B2 proficiency in Portuguese, they are automatically placed into regular Portuguese classes without further differentiated language support. Ultimately, the organization of language support for PNML students is up to individual schools, and they can develop their alternative solutions to meet the aims and objectives. These initiatives focus on developing Portuguese language skills, but are less concerned with the maintenance of students' languages or, in general, organizing bi/multilingual education, so that linguistic diversity is rather seen as a deficit that non-systemic, additional tuition of Portuguese shall solve (Moreira, Duarte and Flores, 2014). For instance, studies showed that teachers were aware of linguistic diversity in the classroom and developed some strategies to differentiate teaching in order to facilitate understanding Portuguese language instruction and Portuguese language learning (Silva and Gonçalves, 2011). Martins and Pereira (2011) recommend acknowledging the characteristics of the different language groups in the classroom and individual learners, and im- 
plementing collaborative learning, formal and informal group work, tutoring in pairs and project work. However, it is still less usual to conceptualize linguistic diversity including migrant and minoritized languages as resources in everyday mainstream education, and to promote multilingual pedagogies in all teachers' practice (regardless of subject area) that mobilize students'languages in schooling. In the case of heritage languages, Faneca, Araújo e Sá and Melo-Pfeifer (2016) discussed that although students' languages were recognized, classroom practices did not seem to build on students' cultural and linguistic identities. The authors concluded that there was no space yet for heritage languages to be taught in Portuguese schools, both due to the lack of a language policy promoting this initiative and because teachers seemed to undervalue the importance of heritage languages in multilingual education. Instead, heritage language lessons and activities are usually organized outside of the national educational system as extracurricular activities, often guided by particular language communities, associations and embassies (e.g., Tereshchenko and Grau Cárdenas, 2013).

Although there have been considerable initiatives in some teacher education faculties in order to introduce aspects of linguistic diversity, Moreira, Duarte and Flores (2014, p. 139) noted that "teacher preparation programs are not yet responding systematically to [...] multilingual reality". Consequently, it is an ever-important issue to explore what strategies teachers in public schools develop in responding to linguistic diversity, and how students' languages are positioned in classroom practice.

\section{RESEARCH OBJECTIVES AND QUESTIONS}

This study is part of a larger project (Szelei, 2019) that aimed at understanding cultural diversity in a Portuguese school cluster. When approaching "cultural diversity", we also focused on the language dimension, since culture and language are closely related, intertwined, and often inseparable concepts (Nieto, 2010). We also found that, in the selected case study, conceptualizations of cultural diversity were often related to language difference and, more narrowly, students who were identified as PNML learners and not yet proficient in Portuguese language. Therefore, acknowledging this school reality, this article provides an account of the strategies mainstream teachers developed in their multilingual classrooms, and how students' languages were positioned in these responses. The study sought answers for the following questions:

- What strategies do teachers develop in order to respond to linguistic diversity?;

- How are students' languages positioned in these strategies?;

- What do these strategies reveal about teachers' multilingual pedagogy awareness as a step to social justice?

This study contributes to a better understanding of the strategies teachers in public schools develop in multilingual classes. This research is an exploratory one in nature, and its aim was to broadly map out and highlight the common points in the strategies that teachers from several schooling phases and disciplines developed. 


\section{METHODOLOGY}

\section{SETTING}

The School Cluster of this case is located in a city in Portugal, in a region that receives a high number of newly arriving migrants. In Portugal, most schools are grouped into a school cluster. In other words, a school cluster includes several schools into the same administrative unit. School clusters also usually have a shared educational vision and plan as an umbrella guide for their schools. While there are still some not-clustered schools, altogether there are 713 school clusters in Portugal located all across the country (República Portuguesa, 2019). One city can have several school clusters. An online search of publicly available school documents and experts' recommendations were considered when purposefully selecting the case of the study according to the selection criteria cultural diversity in the school cluster; and the school cluster's explicit intention to respond to cultural diversity. Four schools out of the six of the School Cluster participated in the research, one secondary school (School A) and three primary ones (School B, C, and D). The School Cluster altogether hosted 32 nationalities. Around 22\% of the student population had nationalities other than Portuguese, and $40 \%$ of this student body are indicated as PNML learners. Across the whole School Cluster, nationalities with the largest number of students were Portuguese, Brazilian, Nepalese, Cape Verdean, Indian, and Bangladeshi. There were also many nationalities represented by one student. In the individual schools, the distribution of nationalities differs. Table 1 demonstrates the nationalities across the schools.

Table 1 - Overview of nationalities in the School Cluster.

\begin{tabular}{lccccc}
\hline & $\begin{array}{c}\text { School } \\
\text { Cluster } \\
\text { (altogether) }\end{array}$ & $\begin{array}{c}\text { School } \\
\text { A }\end{array}$ & $\begin{array}{c}\text { School } \\
\text { B }\end{array}$ & $\begin{array}{c}\text { School } \\
\text { C }\end{array}$ & $\begin{array}{c}\text { School } \\
\text { D }\end{array}$ \\
\hline Number of nationalities & 32 & 23 & 9 & 14 & 7 \\
\hline $\begin{array}{l}\text { Distribution of } \\
\text { Portuguese students } \\
\text { and students with other } \\
\text { nationalities (\%) }\end{array}$ & $78-22 \%$ & $79-21 \%$ & $70-30 \%$ & $59-41 \%$ & $95-5 \%$ \\
\hline $\begin{array}{l}\text { Nationalities other } \\
\text { than Portuguese in the } \\
\text { highest numbers }\end{array}$ & $\begin{array}{l}\text { Bepal, Cape } \\
\text { Verde, India, } \\
\text { Bangladesh }\end{array}$ & $\begin{array}{l}\text { Nepal, } \\
\text { Cape } \\
\text { Verde, } \\
\text { India }\end{array}$ & $\begin{array}{c}\text { Brazil, } \\
\text { Cape } \\
\text { Verde, } \\
\text { Nepal, } \\
\text { India }\end{array}$ & $\begin{array}{c}\text { Brazil, } \\
\text { Bepal, }\end{array}$ & $\begin{array}{c}\text { Brazladesh } \\
\text { Cape } \\
\text { Verde, } \\
\text { Italy, India, } \\
\text { Nepal }\end{array}$ \\
\hline
\end{tabular}

The School Cluster did not have systematically collected information on the languages spoken by the students at the time of this research. The leadership has noticed that, although the School Cluster generally performs below the national average, PNML students present with an even larger gap. Teachers also 
noticed students were often demotivated due to not understanding Portuguese, usually leading to class absences. Therefore, mandatory PNML classes have been established at the secondary level, and small group PNML activities have been arranged at the primary level as well. The School Cluster also created a team responsible for newly arrived students' integration, including tasks such as providing multilingual leaflets about school administration and everyday life, and arranging bilingual parents' meetings where students usually act as translators. This team has also started to prepare subject specific materials and raise awareness among teachers to develop inclusive practices. These initiatives, however crucial, do not necessarily address teaching strategies in the classroom directly. Teachers in this School Cluster report little preparedness for teaching Portuguese language learners, but some have been taking PNML professional courses. Teacher collaboration and professional development, as a shared commitment among the whole staff to respond to linguistic diversity is currently being developed in the School Cluster. It is important to point out that linguistic diversity as a whole in the School Cluster might not only mean PNML learners, even if this is what policy documents mostly mention. It could also include multilingual Portuguese nationals and pupils arriving from countries where Portuguese is an official language.

\section{DESIGN AND DATA COLLECTION}

An embedded case study was applied (Stake, 1995) in order to monitor and understand teaching strategies in multilingual classrooms. Case studies provide a platform for collecting rich descriptions of school practices in terms of their reality: linguistic diversity situated in the school-context and through the interpretation of its stakeholders (Stake, 1995). In this project, the school cluster frames the case, and embedded there are individual schools and individual teachers. In this article, we focused on teachers' strategies contextualized in the School Cluster frame. Participants included 24 teaching staff members from the School Cluster, namely, 16 from School A, 3 from School B, 3 from School C, and 2 from School D. School A is a large school that involves both lower and upper secondary sectors ( $5^{\text {th }}$ to $12^{\text {th }}$ grade), and where all the smaller primary schools feed in. According to qualifications, there were 3 preschool teachers, 11 primary school teachers, and 10 subject teachers on the secondary level. The participants presented with teaching experience varying between 10 and 40 years, and specifically in this school cluster, from 1 to 20 years. While we do not have a systematic account on teachers'languages, we note that their linguistic profiles were different: while some were proficient only in Portuguese, others spoke other languages too, mainly English or French to differing degrees. Data were gathered through multiple qualitative data collection techniques, in three distinct phases:

- school documents and the first round of semi-structured interviews $(\mathrm{n}=6)$ were gathered with participants who were identified as being actively involved or knowledgeable about the School Cluster's programs regarding cultural diversity; 
- a second set of interviews $(n=10)$ was conducted after an initial analysis of data gathered in the first round;

- a third round of interviews $(n=8)$ and classroom observations were performed in the third phase.

Altogether, 7 teachers were observed and registered in field-notes by the first author. 4 teachers were followed once a week for a month (1 preschool teacher, 2 primary classroom teachers, and 1 Natural Sciences secondary teacher), and another 3 for shorter periods (1 PNML primary teacher and 2 Natural Sciences/Chemistry secondary teachers). The observer's role was non-participant, mostly sitting in the classroom, observing and taking notes, aiming to minimize intervention in classroom dynamics as possible.

\section{DATA ANALYSIS}

From these different sources, a text-based dataset was generated. The entire dataset was substantially read in order to gain an overview on the text. Data were analyzed using a constructivist grounded theory approach (Charmaz, 2011) with the NVivo 11 software. The analysis was performed by the first author, and the co-authors reviewed the codes and the findings. The codes were formulated around how they informed the research questions. Category formation involved three main phases moving from coding hard data to assembling more theoretical categories responding to the research questions. First, codes were formulated in vivo, then were grouped and named in gerunds in order to signal the processual rather than the fixed character of teaching strategies (Charmaz, 2011). The codes were simultaneously reviewed in relation to each other, continuously redefined, using constant comparison (Corbin and Strauss, 2008). The codes were then organized around categories that illuminated answers to the research question focusing on how students' languages were positioned within the strategies. Finally, three main categories emerged:

- promoting Portuguese language learning without involving other languages;

- using a shared language (English) as lingua franca;

- using students' languages.

These strategies are not necessarily exclusive to each other in teachers' practices. Teachers might have used one, two or three of these strategies to differing extents in their classroom and/or with the same group of students. The objective of coding the dataset across interview - and observational data stemming from individual cases was to identify these umbrella approaches. The portrayal we offer from this analysis is, therefore, exploratory in nature and sheds light on overarching strategies, rather than a closer investigation of individual teacher's practices. The overview of the strategies in combination with the participants in the dataset can be seen in Table 2 . 
Table 2 - Overarching teaching strategies in responding to linguistic diversity.

Strategy

\begin{tabular}{c|c}
$\begin{array}{c}\text { Interview } \\
\text { data (out of 24 } \\
\text { participants) }\end{array}$ & $\begin{array}{c}\text { Observational } \\
\text { data (out of 7 } \\
\text { participants) }\end{array}$
\end{tabular}

Promoting Portuguese language learning without involving other languages

\begin{tabular}{l|c|c}
\hline Altogether & 21 & 7 \\
\hline Displaying images, drawings & 8 & 7 \\
\hline Using body language, gestures & 3 & 5 \\
\hline Playing games, role plays, other playful exercises & 2 & 5 \\
\hline Demonstrating with objects & 1 & 2 \\
\hline Manipulating or playing with objects & 5 & 3 \\
\hline Using simplified material & 3 & - \\
\hline Using multimodal projects to enhance reading and & 1 & 2 \\
writing & 1 & 3 \\
\hline Playing videos (Portuguese language, no subtitles) & 2 & 4 \\
\hline Repeating in Portuguese & 1 & - \\
\hline Letting Portuguese speaker peers to help Portuguese & 1 & - \\
\hline learners & - & 2 \\
\hline Performing real-life tasks in Portuguese & - & 3 \\
\hline Allowing only speaking Portuguese in the classroom & - & 1 \\
\hline Teacher repeating student talk in correct Portuguese & 18 & - \\
\hline Explaining in Portuguese again but in other words & & \\
\hline Explaining task in Portuguese again but individually & & \\
\hline Expressing insecurity to modify strategies & & \\
\hline Uing a & & \\
\hline
\end{tabular}

Using a shared language (mostly English) as lingua franca

\begin{tabular}{l|c|c}
\hline Altogether & 11 & 6 \\
\hline Speaking English in general, to communicate & 9 & 5 \\
\hline Teaching in English and Portuguese (in general) & 1 & - \\
\hline Speaking English to clarify instruction & 2 & 5 \\
\hline Speaking English to translate learning content & - & 4 \\
\hline Speaking English to teach Portuguese vocabulary & - & - \\
\hline $\begin{array}{l}\text { Letting student explain in English then asking for } \\
\text { repeating in Portuguese }\end{array}$ & 4 & 1 \\
\hline $\begin{array}{l}\text { Using English to translate Portuguese to create } \\
\text { worksheets and learning material for students }\end{array}$ & - & - \\
\hline Playing English video with Portuguese subtitles & 1 & \\
\hline Communicating in Spanish in general & & \\
\hline
\end{tabular}


Table 2-Continuation.

\begin{tabular}{|c|c|c|}
\hline Strategy & $\begin{array}{l}\text { Interview } \\
\text { data (out of } 24 \\
\text { participants) }\end{array}$ & $\begin{array}{l}\text { Observational } \\
\text { data (out of } 7 \\
\text { participants) }\end{array}$ \\
\hline Speaking Spanish to teach Portuguese vocabulary & - & 1 \\
\hline Communicating in French in general & 1 & - \\
\hline \multicolumn{3}{|l|}{ Using students' languages } \\
\hline Altogether & 12 & 4 \\
\hline $\begin{array}{l}\text { Asking students speaking similar languages to translate } \\
\text { to each other in order to understand Portuguese } \\
\text { instruction }\end{array}$ & 4 & 2 \\
\hline $\begin{array}{l}\text { Letting students using phones and iPads to translate } \\
\text { from Portuguese }\end{array}$ & 2 & 2 \\
\hline $\begin{array}{l}\text { Letting students reply in their languages then asking } \\
\text { them to translate to Portuguese }\end{array}$ & 1 & - \\
\hline $\begin{array}{l}\text { Teacher using Google to translate Portuguese } \\
\text { worksheet or material into students' languages }\end{array}$ & 2 & - \\
\hline Teacher learning a few words in students' languages & 3 & - \\
\hline $\begin{array}{l}\text { Students teaching a few words in their languages to } \\
\text { whole class }\end{array}$ & 1 & - \\
\hline $\begin{array}{l}\text { Students reading stories, poems, performing a play in } \\
\text { their languages to whole class }\end{array}$ & 2 & - \\
\hline $\begin{array}{l}\text { Students writing short sentences in their languages on } \\
\text { artwork }\end{array}$ & - & 1 \\
\hline Asking students what languages they speak & - & 1 \\
\hline $\begin{array}{l}\text { Teacher telling the whole class what languages a } \\
\text { student speaks }\end{array}$ & - & 1 \\
\hline
\end{tabular}

\section{FINDINGS}

Hereby we explore the three overarching strategies that teachers applied in responding to linguistic diversity. We unpack each category by giving a descriptive account of the specific techniques within those strategies, explaining how students' languages were positioned, and whether these strategies showed signs of awareness for multilingual pedagogies. These categories are not exclusive to each other, some teachers moved between them during their practices. It is important to note that teachers' responses to linguistic diversity were strongly dominated by what they referred to as PNML, just as in the policy framework they operated in. Only a few teachers mentioned multilingual learners in terms of Portuguese nationals or incoming students from countries where Portuguese is an official language. The fact that students (with or without PNML status) might be multilingual was mentioned only twice across the whole data. 


\section{PROMOTING PORTUGUESE LANGUAGE LEARNING}

\section{WITHOUT INVOLVING OTHER LANGUAGES}

Most teachers were concerned with students' Portuguese language development as indispensable to succeed in the Portuguese educational system and society in general. Teachers seemed concerned that without Portuguese language proficiency students would not manage in school and in life in Portugal. Therefore, most teachers were focused on the importance of knowing the language of schooling, and applied strategies in a way they did not involve languages other than Portuguese. Teachers often reported using images, drawings, videos, computers, body language and gestures, and objects as demonstratives in order for students to understand Portuguese language instruction or teaching content. It also seemed that, especially primary and preschool teachers favored playful activities where students play, manipulate objects and learn Portuguese at the same time, as a way of teaching and learning for young learners. Teachers sometimes also asked Portuguese-speaking students to help PNML students. For example: "So, it is necessary to use, for example, lots of images, very concrete things, point at objects, do actions with them [students] in a role play or joint game... so that they understand what I asked and they understand how it has to be done" (Interview, School B, Preschool Teacher); "I had to be making drawings" (Interview, School A, Secondary Teacher).

These instructional strategies mostly involving images, drawings, or multimodal methods (combining technology, image, and sound) in order to enhance Portuguese language development were usually techniques teachers already used in their practices, but now emphasized more and reformulated for a different audience (PNML) and with a different educational aim: to learn Portuguese language. For example, using images or objects to demonstrate subject content is a usual technique for all students, but this time the teachers felt a greater need for these pointers for PNML students, as these techniques did not only help developing knowledge in the subject area, but facilitate Portuguese vocabulary development and understanding Portuguese instruction. To enhance Portuguese speaking, the teachers sometimes simply asked students to repeat words after them, or themselves repeated students' talk in a corrected form. For example,

"Me-ni-na" [girl] told the teacher to X ['PNML' student] and clapped three times according to the syllables. He did it again and asked $X$ to repeat. This followed three more times. The teacher then stopped clapping, but kept on articulating each syllable loudly, pausing for $X$ to repeat after him. They did this many times because $X$ had difficulties articulating " $M E$ " the correct way. The teacher then just repeated the syllable $M(e)-M(e) \ldots$ and $X$ repeated after him. After a few moments, silence fell on the classroom and only the teacher's and $X$ 's voice was audible - the teacher articulating " $M(e)$ " firmly and loudly, and X struggling to pronounce after him. A chant of $M(e)-M e$ was heard in the classroom while the others copied the text from the blackboard. (Field-note, 25.10.2017, School C, Primary School) 
Primary and secondary teachers reported more difficulties with responding to linguistic diversity. While preschool and some primary school teachers believed that children learn Portuguese quickly simply by being in school and interacting with their peers, worries raised as children's age increased. Most teachers were concerned with fulfilling the national curriculum and passing the national tests that are strictly in Portuguese; and therefore, felt their duty was to focus on Portuguese language development, as the most important mean of supporting students in raising their academic achievement. In addition to the aforementioned tools, these teachers also started to differentiate learning material, and employed simplified tasks for PNML students, as gradual steps to reaching the mandated level of Portuguese: "For example, in terms of teaching methodology, what I do is, the difficulty level of the task, if I know that the tasks will be more difficult... they don't speak well, they don't write Portuguese well, this way I [adjust] the task to their levels" (Interview, School A, Secondary Teacher).

Many teachers reported doubts, powerlessness or struggle in modifying strategies, especially in secondary schools. Teachers expressed feelings of helplessness and frustration in dealing with linguistic diversity. This feeling of anxiety seemed to arise from several reasons, such as insecurities in communicating with students, lack of pedagogical knowledge to modify strategies, lack of materials and resources, and constrains in national and local context. For example: "I think that sometimes I'm the one who feels more inhibited, when they start all speaking in their language and I don't understand anything" (Interview, School D, Primary Teacher);

But I felt quite incapable of dealing with all. That is, teaching those who master the language, make them go forward, when they already are at completely different stages amongst themselves, try to work in different ways with pupils who are at different... stages, and, even more, those pupils who don't understand the language, who I need to support and to whom I also need to... teach the curriculum! How is this done?! (Interview, School A, Secondary Teacher)

"To manage to put them in practice... (it is) simply impossible because there is no time and no room (for it)" (Interview, School C, Primary Teacher).

These teachers' struggles deriving from contextual constrains many times led to teachers' perceived powerlessness to change practice and, consequently, to maintaining the regular Portuguese-medium lessons without modifications, and continue "teaching as usual". Although teachers were aware that this situation might be demotivating and unfair for students, they also felt doubtful about changing their practices or the Portuguese system itself. For example: "I have already met pupils who simply didn't attend classes because they didn't understand the language, they excluded themselves. And we tried to explain that they had to attend the class anyway" (Interview, School A, Secondary Teacher).

The strategies in this category therefore show two distinct ways of responding to linguistic diversity with the overall aim to teach Portuguese language. One is a slight modification of strategies using tools that already existed in teachers' pedagogical repertoire, but now applied with a different emphasis, reason, and target group. 
These techniques supported understanding Portuguese instruction and vocabulary development. In this sense, teachers made basic efforts in supporting Portuguese language learners to succeed in Portuguese schooling. On the other hand, another set of responses, deriving from teachers' insecurities in how to change practices and feeling dependent on contextual constraints, teachers often left strategies unmodified; and therefore, students left to manage learning on their own. Strategies in this category did not seem to apply multilingual pedagogy that treats languages as interacting systems, and builds on students' linguistic repertoires and metalinguistic awareness. Teachers also did not seem to make connections between students' languages and Portuguese language development, but the underlying assumption seemed to be that students learn Portuguese fastest when Portuguese is the only or the dominant language of schooling. Consequently, a strong monolingual rather than multilingual vision guided the strategies developed for enhancing Portuguese language development.

\section{USING A COMMON LANGUAGE (ENGLISH) AS LINGUA FRANCA}

Another main strategy teachers developed was to find a shared language between the teachers' and students' linguistic repertoires, and use it as means of mediation between students' languages and the Portuguese language of schooling. A strongly emerging theme was using English as lingua franca, but a few teachers mobilized their French or Spanish, depending on which languages students and the teachers spoke in common. English then was mostly used in terms of being able to communicate with students in general, to provide basic information on administrational issues and schooling. "To be able to talk to them, I use English (Interview, School B, preschool) I speak English to them" (Interview, School A, secondary teacher), teachers noted. Furthermore, in some cases, English became a part of the language of instruction for mainstream lessons or the creation of learning materials. These times, teachers specifically addressed PNML students and spoke to them in English in order to check if they understood what the task was, to clarify instruction, to teach Portuguese vocabulary, or to explain content material. These instances were episodic in the classroom interaction, and their extent varied between teachers: "I always try to explain to them during the lessons where I am in the textbook... sometimes [I say]: attention, we are talking about... you have to turn the page to... and you have to write these in your notebook because" (Interview, School A, Secondary Teacher).

Two cases showed that English was not only episodic in explaining subject content, but it became a parallel, simultaneous language of instruction. Teachers here explained the material first in Portuguese, and repeated it in English afterward, specifically targeting two different audiences: Portuguese speakers and PNML students. It seemed that the Portuguese and English languages were kept as separate units for distinct audiences, rather than a multilingual approach toward all learners. For example, the next excerpt is from a primary class Mathematics lesson where the teacher usually translated the tasks and materials into English, specifically targeting PNML students. 
The teacher continued reading the task [word problem] from the worksheet. The task was similar to the one before, only now it asked if there were 12 roses on a branch, bow many branches they bad to buy to reach the necessary number of roses. The teacher read the word problem in Portuguese, and told the children to start solving the exercise. $X$ and $Y$ ["PNM" students] asked "What's that?" "Oh sorry, I did not say in English." Replied the teacher "One, it's from the same problem. For having the 15 group of flowers, they need 60 roses. But the roses come in the groups of 12 . How

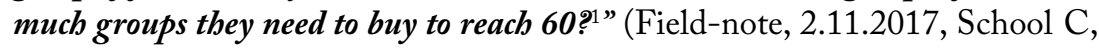
Primary School)

However, English was not always a shared language between the teachers' and the students' linguistic repertoires, as neither every teacher nor every student spoke English.In these cases, teachers usually reported a complete feeling of helplessness. Consequently, teachers even asked for English language courses as professional development opportunities to be able to communicate with pupils: "It's very hard. When one masters the English language there are always tools that we can use, when there isn't... when there's no touching point it is horrible for the kids. And for us it is also frustrating" (Interview, School A, Secondary Teacher).

In short, using English as a lingua franca in the mainstream Portuguese classroom mainly had two aims: it showed teachers' willingness to communicate with students; and to teach Portuguese subject content. Teachers made efforts to translate content material into English and talk to students in English in general, even if neither teachers' nor students' languages at home were English. This tendency shows a clear sign of teachers' attempt to connect with students and provide some support, so that students could navigate themselves through the lessons. English entered some of these mainstream classrooms where traditionally only Portuguese would be used. However, the use of English instruction was kept specifically for PNML learners, constantly signaling their different Portuguese proficiency status in the classroom, rather than operationalizing it within a bi/multilingual paradigm, where English instruction might also benefit those proficient in Portuguese. Moreover, although English was part of many students' linguistic repertoires, it might not have been the language they spoke at home or with their friends at school.

\section{USING STUDENTS' LANGUAGES}

Although the majority of responses were promoting Portuguese without involving other languages or using English as lingua franca, to a small extent some strategies involved students' languages too. Some teachers on the secondary level let students use their mobile phones or provided iPads to translate during the lessons in order to understand Portuguese language teaching material and instructions during the lessons. In these instances, the teachers welcomed any languages students themselves selected for translating for the ultimate goal of understanding the lesson and subject material. Some teachers also encouraged pair-work between students

$\overline{1 \text { Words in bold }}$ were spoken in English in a Portuguese-medium classroom. 
whose languages were similar, in order to perform translations together, and to learn Portuguese subject-specific vocabulary during the lesson. However, these initiatives depended on technology which sometimes failed to operate. Although these opportunities provided a space in the classroom where students could develop the language of schooling and use their own languages as resources, students were in fact left in a passive role, isolated in their own units. For example,

The teacher walked to the back to Y ("PNML" student) and asked her in English "Did you understand? We are studying competition between plants. And so, what's happening there?" she pointed to the image in the girl's textbook that was open in front of her on the desk "You can use your phone to translate, to see what's the result." The girl took the teacher's advice and used a programme on her phone for translating the words in the textbook into a language she chose (not English). She took pictures with the phone of the texts in the books, and the programme somehow figured the translation for her. She looked at the screen of the phone and copied the translations into her notebook. She worked individually during the whole time of the task. (Field-note 29.11.2017, School A, Natural Sciences lesson)

Very few strategies that incorporated students' languages showed a change in viewing majority-minority language positions in the teaching-learning process. These extremely few instances showed willingness from the teachers' side to inquire about students' languages, to learn a few words themselves, and even more rarely, to make those languages the medium of an activity for the whole class: "They were all happily reading Russian, explaining the story in Russian, as if everybody would understand. It was very nice" (Interview, School B, Primary Teacher).

The strategies in this category therefore positioned students' languages in two different ways. One logic was allowing students to use their languages in order to facilitate Portuguese language development and the understanding of Portuguese. In this sense, students' languages were present and allowed in the Portuguese-medium lessons, and served as bridges in the learning of Portuguese. Students' languages hereby also remained for the sole use of PNML students, who usually worked in separately, alone or with a peer who spoke similar languages to manage participating in the lessons. The second logic of using students' languages was legitimizing those as the mediating language of an activity for short periods of time. In these moments, students' languages became equal to the language of schooling, and were shared with a larger audience. Here, teachers aimed at valuing students' languages and identities and not only the languages related to PNML were involved, but any other that students represented. However, these activities remained sporadic and marginal in the domination of subject content teaching through a monolingual Portuguese lens.

\section{DISCUSSION AND CONCLUSIONS}

The purpose of this article was to explore the strategies mainstream teachers applied in responding to linguistic diversity in a school cluster in Portugal. 
Special attention was given to how students' languages were positioned in those strategies, as the involvement of students'languages is a cornerstone in developing socially just practices for linguistic diversity (Skutnabb-Kangas et al., 2009). It was also considered how teachers embedded in monolingual language policies can negotiate linguistic diversity in their multilingual classrooms by the teaching strategies they develop.

This research detected a variety of strategies that teachers applied as responses to linguistic diversity: promoting Portuguese without involving students' languages, using English as a mediation language between students' languages and Portuguese, and using students' languages in the teaching-learning process. These strategies were not exclusive to each other; in fact, teachers in their everyday lives might have applied one or another as they prioritized Portuguese language development, communicating with students or affirming students' linguistic identities. These main aims (developing language of schooling, connecting with students, valuing students' identities) have been present in teachers' practices in an intertwined way that shows teachers' awareness for the multiple aims of education and that they somewhat tried to satisfy curricular, social, and students' needs between the monolingual policy setting and the multilingual classroom reality. Throughout these dynamics, they developed several strategies that were seen as negotiating mechanisms developed in human interaction (McCarty, 2004; 2011; Shohamy, 2006) between teachers, students, and curricula; and that revealed possible fruitful starting points even in contexts largely affected by monolingual policies (Hélot, 2010; Bonacina-Pugh, 2017; Mary and Young, 2018).

However, when looking into the overarching strategies closely, we found several limitations of these negotiating pedagogical mechanisms. First, there was a clear dominance of prioritizing Portuguese language development in which students' languages received little recognition, and hardly in their own value. Secondly, all three strategies were enacted through a monolingual vision on languages and learning that kept languages and student groups separate; and implied teachers' little awareness for multilingual pedagogies. Finding specific correlations between the strategies and underlying reasons is beyond the scope of this article, but we can indicate a few possibilities for explanations. Teachers' own linguistic repertoires and multilingual skills, monolingual beliefs, and ideologies (De Angelis, 2011; Asker and Martin-Jones, 2013; Gu and Qu, 2015; Pulinx, Van Avermaet and Agirdag, 2017), contextual circumstances (Faneca, Araújo e Sá and Melo-Pfeifer, 2016; Kirsch, 2018; Tarnanen and Palviainen, 2018), or learning opportunities might all shed light on explaining what might underpin these findings. Since the teachers in this study did not receive professional development in multilingual pedagogies, it is not surprising that they relied on the pedagogical repertoire they were already familiar with, which is teaching through the Portuguese medium. Some attended PNML training courses, but it remains unknown how these PNML courses were aligned with multilingual pedagogies. Therefore, the lack of multilingual pedagogies in their initial teacher education and professional development could explain why all three detected strategies seemed to be enacted through a monolingual vision. These findings are consistent with other studies claiming that teachers need more 
support in developing multilingual pedagogies in the classroom, as well as a focus on social justice within (Anderson et al., 2010; de Mejia and Hélot, 2015). The danger within such enactments lies in separating groups into majority ones and others (Shohamy, 2006) on the basis of externally prescribed language status that disregards fluid linguistic repertoires and, generally, the benefits of learning multiple languages for all. The separation of groups was remarkable when Portuguese language learners were marginalized in classroom instruction, even when languages other than Portuguese were involved. For example, using English in the classroom in this study was clearly a positive effort from the teachers' side to connect with students and ensure they understand instruction. However, the way these English language instructions were performed specifically targeted PNML learners, usually calling their names out loud and treating English and Portuguese language as separate units for separate students. Similarly, when students were allowed to use their languages in translations, they still often remained in a passive, isolated role. Very few strategies involved students' languages in the classroom interaction as equals and, for a few moments, broke the binary of minority and majority languages.

Consequently, regarding the position students' languages received in these strategies, it seemed students' languages were either absent or in a few cases, regarded as bridges to learning Portuguese, but not as entities in their own value and as part of a strategy to include and recognize students' linguistic identities. This finding is coherent with other studies in Portugal that displayed teachers' concerns and techniques applied for fostering Portuguese language development, but explored less how students' languages were approached, or depicted the hardship in Portugal for heritage languages to strive (Silva and Gonçalves, 2011; Faneca, Araújo e Sá and Melo-Pfeifer, 2016). Furthermore, teachers did not seem to be aware of or critique the dominance of Portuguese language in a multilingual school where students represent a wide variety of languages. Neither did they make connections between the importance of providing learning opportunities to utilize students' whole linguistic repertoires as resources in order to support students' self-identification and metalinguistic awareness. Consequently, students remained most of the time in situations where their languages were neglected, or allowed to be used for the sake of understanding the language of schooling. Teachers, even if unaware, struggled to view students with integrative, holistic linguistic repertoires that need to be promoted in all their facets (Pinho and Moreira, 2012), possibly constraining the legitimacy students' identities and their development in schooling.

The findings can also be related to how Portuguese language policy context frames students and teaching-learning. In policy terms, students seem to be solely defined by knowing or not knowing Portuguese, thus erasing a whole range of linguistic repertoires, including recently arriving migrants, as well as students born in Portugal or arriving from countries where Portuguese is an official language, but whose languages might not only be Portuguese. The limitations in conceptualizing linguistic identities in language policy, as well as the prevalence of the PNML paradigm in Portugal might be one circumstantial element in explaining why teachers themselves talk of students as PNML and overwhelmingly develop strategies that target overcoming not being proficient 
in Portuguese while being unaware of multilingual pedagogies that would target all students while taking into account their linguistic repertoires and different learning needs through the principle of "singularity in plurality" (García and Sylvan, 2011). Evidently, this is not to forget about the specific challenges those students encounter, who are not yet proficient in the language of schooling. It is probable that specifically in this study, where PNML students underperformed the rest, and where for many teachers PNML students were a somewhat new classroom reality, teachers felt that developing strategies specifically for this group of students is more urgent.

Despite these limitations, the teachers in this School Cluster made a few steps to negotiate the strict monolingual system. The involvement of English and students' languages in classroom strategies, which is currently practiced in limited ways, could be springboards for transforming the "multilingual habitus" (Benson, 2014) when teachers are aware of and feel confident to apply multilingual pedagogies. There were also a few activities, that although representing a very small proportion of the School Cluster, showed that some teachers were aware of the importance of involving students' and their languages as equal, active creators of knowledge in the teaching-learning process. In these moments, teachers explicitly instructed students to use their chosen languages and through these teacher actions, students' languages became visible and equal for some moments in school life. These initiatives might bridge home - and school languages, as well as contribute to students' self-identification, and feeling of belonging to school (Miller, 2004; Van Der Wildt, Van Avermaet and Van Houtte, 2017). Such activities are crucial for students who might spend most of their school time silenced, not given the opportunity to express themselves, and therefore might feel their identities dismissed.

The findings of this study portrayed that teachers can somewhat negotiate even strict language policy contexts (Hélot, 2010; Hélot and Ó Laoire, 2011; Jordens, Van Den Branden and Van Gorp, 2018; Mary and Young, 2018), yet these are one-off, teacher-dependent actions rather than shared commitment and systemic acceptance of multilingualism. Consequently, this study shows that there is a continued need to build systemic structural support for teachers and students to introduce multilingual pedagogies into education and teacher education.

\section{REFERENCES}

ANDERSON, J. et al. Professional development for staff working in multilingual schools. In: THE RIGHT OF LEARNERS TO QUALITY AND EQUITY IN EDUCATION-THE ROLE OF LINGUISTIC AND INTERCULTURAL COMPETENCES, Geneva, November 2010. Document [...]. Strasbourg: Council of Europe, 2010.

AGIRDAG, O. Exploring bilingualism in a monolingual school system: Insights from Turkish and native students from Belgian schools. British Journal of Sociology of Education, v. 31, n. 3, p. 307-321,2010. https://doi.org/10.1080/01425691003700540 
ASKER, A.; MARTIN-JONES, M. "A classroom is not a classroom if students are talking to me in Berber": Language ideologies and multilingual resources in secondary school English classes in Libya. Language and Education, v. 27, n. 4, p. 343-355, 2013. https://doi.org/10.1080/09500782.2013.788189

BALL, A. F.; TYSON, C. A. Preparing teachers for diversity in the twenty-first century. In: BALL, A. F.; TYSON, C. A. (ed.). Studying diversity in teacher education. Lanham: Rowman \& Littlefield, 2011. p. 399-416.

BENSON, C. Adopting a multilingual habitus: What North and South can learn from each other about the essential role of non-dominant languages in education. In: GORTER, D.; ZENOTZ, V.; CENOZ,J. (ed.). Minority languages and multilingual education. Dordrecht: Springer, 2014. p. 1-28.

BONACINA-PUGH, F. Legitimizing multilingual practices in the classroom: The role of the "practiced language policy". International Journal of Bilingual Education and Bilingualism, v. 23, n. 4, p. 434-448, 2017. http://doi.org/10.1080/13670050.20 17.1372359

BUTCHER, J.; SINKA, I.; TROMAN, G. Exploring diversity: Teacher education policy and bilingualism. Research Papers in Education, v. 22, n. 4, p. 483-501, 2007. https://doi.org/10.1080/02671520701651102

CAJKLER, W.; HALL, B. "When they first come in what do you do?" English as an additional language and newly qualified teachers. Language and Education, v. 23, n. 2, p. 153-170, 2009. https://doi.org/10.1080/09500780802308851

CENOZ, J.; GORTER, D. Towards a plurilingual approach in English language teaching: Softening the boundaries between languages. Tesol Quarterly, v. 47, n. 3, p. 591-599, 2013. https://doi.org/10.1002/tesq.121

CHARMAZ, K. Grounded theory methods in social justice research. In: DENZIN, N. K.; LINCOLN, Y. S. (ed.). The Sage handbook of qualitative research. Los Angeles: Sage, 2011. p. 359-381.

CORBIN, J.; STRAUSS, A. Basics of qualitative research: techniques and procedures for developing grounded theory. 3. ed. Thousand Oaks: Sage, 2008.

CUMMINS, J. A Proposal for action: strategies for recognizing heritage language competence as a learning resource within the mainstream classroom. Modern Language Journal, v. 89, n. 4, p. 585-592, 2005.

DE ANGELIS, G. Teachers' beliefs about the role of prior language knowledge in learning and how these influence teaching practices. International Journal of Multilingualism, v. 8, n. 3, p. 216-234, 2011. https://doi.org/10.1080/14790718.20 11.560669

DE MEJIA, A.; HÉLOT, C. Teacher education and support. In: WRIGHT, W. E.; BOUN, S.; GARCIA, O. (ed.). The handbook of bilingual and multilingual education. West Sussex: Wiley Blackwell, 2015. p. 270-282.

FANECA, R. M.; ARAÚJO E SÁ, M. H.; MELO-PFEIFER, S. Is there a place for heritage languages in the promotion of an intercultural and multilingual education in 
the Portuguese schools? Language and Intercultural Communication, v. 16, n. 1, p. 44-68, 2016. https://doi.org/10.1080/14708477.2015.1113751

GARCÍA, O. Critical multilingual language awareness and teacher education. In: CENOZ, J.; GORTER, D.; MAY, S. (ed.). Language awareness and multilingualism. Switzerland: Springer International Publishing, 2017. p. 263-272.

GARCÍA, O.; SYLVAN, C. Pedagogies and practices in multilingual classrooms: Singularities in pluralities. The Modern Language Journal, v. 95, n. 3, p. 385-400, 2011. https://doi.org/10.1111/j.1540-4781.2011.01208.x

GOGOLIN, I. Linguistic and cultural diversity in Europe: A challenge for educational research and practice. European Educational Research Journal, v. 1, n. 1, p. 123-138, 2002. https://doi.org/10.2304\%2Feerj.2002.1.1.3

GU, M. M.; QU, X. D. Ideological disqualification in language use: being newcomers in primary education. Research Papers in Education, v. 30, n. 4, p. 506-522, 2015. https://doi.org/10.1080/02671522.2014.970227

HAUKAS, A. Teachers' beliefs about multilingualism and a multilingual pedagogical approach. International Journal of Multilingualism, v. 13, n. 1, p. 1-18, 2016. https:// doi.org/10.1080/14790718.2015.1041960

HÉLOT, C. Tu sais bien parler maîtresse!: Negotiating languages other than French in the primary classroom in France. In: MENKEN, K.; GARCIA, O. (ed.). Negotiating language policies in schools. New York: Routledge, 2010. p. 52-72.

HÉLOT, C.; Ó LAOIRE, M. Language policy for the multilingual classroom: pedagogy of the possible. Bristol: Multilingual Matters, 2011.

HÉLOT, C.; YOUNG, A. The notion of diversity in language education: Policy and practice at primary level in France. Language, Culture and Curriculum, v. 18, n. 3, p. 242-257, 2005. https://doi.org/10.1080/07908310508668745

JORDENS, K. K.; VAN DEN BRANDEN, K.; VAN GORP, K. Multilingual islands in a monolingual sea: Language choice patterns during group work. International Journal of Bilingual Education and Bilingualism, v. 21, n. 8, p. 943-955, 2018. https:// doi.org/10.1080/13670050.2016.1220488

KIRSCH, C. Dynamic interplay of language policies, beliefs and pedagogy in a preschool in Luxembourg. Language and Education, v. 32, n. 5, p. 444-461, 2018. https://doi.org/10.1080/09500782.2018.1487452

LYONS, Z. Articulating a deficit perspective: A survey of the attitudes of post-primary English language support teachers and coordinators. Irish Educational Studies, v. 29, n. 3, p. 289-303, 2010. https://doi.org/10.1080/03323315.2010.498568

MARTINS, C.; PEREIRA, I. Metodologias de ensino de PL2 à medida dos aprendentes. Múltiplos Olhares sobre o Bilinguismo, p. 45-65, 2011.

MARY, L.; YOUNG, A. Parents in the playground, headscarves in the school and an inspector taken hostage: exercising agency and challenging dominant deficit discourses in a multilingual pre-school in France. Language, Culture and Curriculum, v. 31, n. 3, p. 318-332, 2018. https://doi.org/10.1080/07908318.2018.1504403 
MATEUS, M. H. M. Diversidade linguística na escola Portuguesa. Revista Lusofóna de Educação, v. 18, n. 18, p. 13-24, 2011.

MCCARTY, T. L. Dangerous difference: A critical- historical analysis of language education policies in the United States. In:TOLLEFSON,J.W.;TSUI, A. B. M. (ed.). Medium of instruction Policies: Which agenda? Whose agenda? Mahwah: Lawrence Erlbaum, 2004. p. 71-93.

MCCARTY, T. L. Ethnography and language policy. New York: Routledge, 2011.

MEIER, G. Our mother tongue is plurilingualism: A framework of orientations for integrated multilingual curricula. In: $\mathrm{CONTEH}, \mathrm{J}$; MEIER, G. (ed.). The multilingual turn in languages education. Bristol: Multilingual Matters, 2014. p. 132-157.

MILLER, J. Identity and language use: the politics of speaking ESL in schools. In: PAVLENKO, A.; BLACKLEDGE, A. (ed.). Negotiation of identities in multilingual contexts. Clevedon: Multilingual Matters, 2004. p. 290-316.

MOREIRA, M. A.; DUARTE, J.; FLORES, C. Teacher education curriculum for teaching immigrant students in Portuguese schools. Sustainable Multilingualism, n. 4, p. 132-148, 2014. http://dx.doi.org/10.7220/2335-2027.4.9

NIETO, S. Language, culture, and teaching: Critical perspectives for a new century. New York: Routledge, 2010.

OLIVEIRA, C. R.; GOMES, N. Indicadores de integração de imigrantes: relatório estatístico anual 2018. Lisboa: OMI ACM, 2018.

PEREIRA, D. Projecto Diversidade Linguística na Escola Portuguesa. In: COLÓQUIO SOBRE POLÍTICAS DE LÍNGUA E DIVERSIDADE, Lisbon, 2006. Paper [...]. Lisbon: Fundação Calouste Gulbenkian, 2006.

PILLER, I. Linguistic diversity and social justice: an introduction to applied sociolinguistics. Oxford, New York: Oxford University Press, 2016.

PINHO, A. S.; MOREIRA, G. Policy in practice: Primary school English teachers learning about plurilingual and intercultural education. L1 Educational Studies in Language and Literature, v. 12, p. 1-24, 2012. http://doi.org/10.17239/ L1ESLL-2012.02.04

PULINX, R.; VAN AVERMAET, P.; AGIRDAG, O. Silencing linguistic diversity: The extent, the determinants and consequences of the monolingual beliefs of Flemish teachers. International Journal of Bilingual Education and Bilingualism, v. 20, n. 5, p. 542-556, 2017. https://doi.org/10.1080/13670050.2015.1102860

REPÚBLICA PORTUGUESA. Direção-Geral da Administração Escolar. Códigos de Agrupamentos de Escolas / Escolas não Agrupadas da Rede do Ministério da Educação. Portugal: Ministério da Educação, 2019. Available at: https://www.dgae. mec.pt/?wpfb_dl=35533. Accessed on: Sep 12, 2020.

RODRÍGUEZ-IZQUIERDO, R. M.; FALCÓN, I. G.; PERMISÁN, C. Teacher beliefs and approaches to linguistic diversity. Spanish as a second language in the inclusion of immigrant students. Teaching and Teacher Education, v. 90, 103035, 2020. https://doi.org/10.1016/j.tate.2020.103035 
SHOHAMY, E. Language policy: hidden agendas and new approaches. New York: Routledge, 2006.

SILVA, M. C. V.; GONÇALVES, C. Diversidade linguística no sistema educativo Português: Necessidades e práticas pedagógicas no ensino básico e secundário. Lisboa: Alto Comissariado para a Imigração e Diálogo Intercultural, 2011. (Observatório da Imigração, 46).

STAKE, R. The art of case study research. Thousand Oaks: Sage, 1995.

SKUTNABB-KANGAS, T. R. et al. Social justice through multilingual education. Clevedon: Channel View Publications, 2009.

SZELEI, N. Unpacking cultural diversity from a critical perspective lens: conceptualisations, practices and professional development in a Portuguese case study In: SCHRATZ, M. et al. (ed.).European Doctorate in Teacher Education: researching policy and practice. Wroclaw: University of Lower Silesia Academic, 2019. p. 180-192. TARNANEN, M.; PALVIAINEN, A. Finnish teachers as policy agents in a changing society. Language and Education, v. 32, n. 5, p. 428-443, 2018. https://doi.org/10.10 80/09500782.2018.1490747

TERESHCHENKO, A.; GRAU CÁRDENAS, V.V.Immigration and supplementary ethnic schooling: Ukrainian students in Portugal. Educational Studies, v. 39, n. 4, p. 455-467, 2013. https://doi.org/10.1080/03055698.2013.778194

TICHELOVEN, A. et al. Translanguaging challenges in multilingual classrooms: scholar, teacher and student perspectives. International Journal of Multilingualism, p. 1-24, 2019. https://doi.org/10.1080/14790718.2019.1686002

TOMÁS, M. I. et al. From emigration to immigration: Towards an assessment of immigration language policies in Portugal. In: HERRERAS, J. C. (ed.). L'Europe des 27 et ses Langues. Valencia: Presses Universitaires de Valenciennes, 2011. p. 463-480. VAISH, V. Teacher beliefs regarding bilingualism in an English medium reading program. International Journal of Bilingual Education and Bilingualism, v. 15, n. 1, p. 53-69, 2012. https://doi.org/10.1080/13670050.2011.594496

VAN DER WILDT, A.; VAN AVERMAET, P.; VAN HOUTTE, M. Multilingual school population: Ensuring school belonging by tolerating multilingualism. International Journal of Bilingual Education and Bilingualism, v. 20, n. 7, p. 868882, 2017. https://doi.org/10.1080/13670050.2015.1125846

VARGAS, F.J.; SANHUEZA, C.M. Diversidad, modelos de gestión y formación inicial docente: Desafíos formativos desde una perspectiva de justicia social. Revista Brasileira de Educação, v. 23, e23005, 2018. https://doi.org/10.1590/s1413-24782018230005

\section{ABOUT THE AUTHORS}

Nikolett Szelei holds a $\mathrm{PhD}$ in European teacher education from the ty of Innsbruck (Austria), in co-tutelle with Universidade Lisboa (Portugal). She is a researcher at Ghent University (Belgium).

E-mail: nikolett.szelei@ugent.be 
Ana Sofia Pinho holds a PhD in language didactics specializing in teacher education from the University of Aveiro (Portugal). She is a professor at the Universidade de Lisboa (Portugal).

E-mail: aspinho@ie.ulisboa.pt

Luís Alexandre da Fonseca Tinoca holds a $\mathrm{PhD}$ in science education from the University of Texas (United States). He is a professor at the Universidade de Lisboa (Portugal).

E-mail:1tinoca@ie.ulisboa.pt

Conflicts of interests: The authors declare that they don't have any commercial or associative interest that represents conflict of interests towards the manuscript.

Funding: This work is part of the EDiTE project that has received funding from the European Union's Horizon 2020 research and innovation program under the MarieSklodowska-Curie grant agreement number (676452).

Authors'contribution: Project Administration, Formal Analysis, Conceptualization, Data Curation, Writing — First Draft, Investigation: Szelei, N. Methodology, Writing — Review and Edition: Szelei, N.; Pinho, A. S.; Tinoca, L. Supervision, Validation: Pinho, A. S.; Tinoca, L. Funding Acquisition: Tinoca, L.

Received on April 10, 2020

Approved on September 17, 2020 